\title{
Adapting Seasonal Sheep Production to Year-Round Fresh Meat and Halal Market in Norway
}

\author{
Muhammad Azher Bhatti ${ }^{1,2, *(\mathbb{D})}$, Thomas Williams ${ }^{3}\left(\mathbb{D}\right.$, David Laurence Hopkins ${ }^{3,4} \mathbb{C}$, \\ Leif Jarle Asheim ${ }^{5}$, Geir Steinheim ${ }^{1}$, Michael Campbell ${ }^{3}$, Lars Olav Eik ${ }^{6}$, Peter Charles Wynn ${ }^{3}$ \\ and Tormod Ådnøy ${ }^{1}$ (D) \\ 1 Department of Animal and Aquacultural Sciences (IHA), Faculty of Biosciences, Norwegian University of \\ Life Sciences (NMBU), P.O. Box 5003, 1432 Ås, Norway; geir.steinheim@nmbu.no (G.S.); \\ tormod.adnoy@nmbu.no (T.Å.) \\ 2 Fatland Ølen AS, Kvassteinsvegen 2, 5580 Ølen, Norway \\ 3 Graham Centre for Agricultural Innovation, Charles Sturt University, Wagga Wagga, NSW 2650, Australia; \\ twilliams@csu.edu.au (T.W.); david.hopkins@dpi.nsw.gov.au (D.L.H.); mcampbell@csu.edu.au (M.C.); \\ pwynn@csu.edu.au (P.C.W.) \\ 4 NSW Department of Primary Industries, Centre for Red Meat and Sheep Development, P.O. Box 129, Cowra, \\ NSW 2794, Australia \\ 5 Norwegian Institute of Bio-economy Research (NIBIO), P.O. Box 1430, Ås, Norway; \\ Leif-Jarle.Asheim@nibio.no \\ 6 Department of International Environment and Development Studies (Noragric), Norwegian University of \\ Life Sciences, P.O. Box 5003, 1433 Ås, Norway; lars.eik@nmbu.no \\ * Correspondence: muhammad.azher.bhatti@nmbu.no; Tel.: +47-4864-3537
}

Received: 5 February 2019; Accepted: 8 March 2019; Published: 14 March 2019

check for updates

\begin{abstract}
Norway is the largest sheep meat producer among Nordic countries with more than 1.3 million lambs and sheep slaughtered in 2017. The sheep industry is limited by the need for in-house feeding during the winter months. In summer, Norwegian sheep are mainly kept on rangeland pastures, with sufficient feed for almost double the current sheep population. Lambs are slaughtered over a three- to four-month period from September to December with a peak in September-October, providing a surplus of lamb, much of which is subsequently frozen, followed by eight months during which fresh produce is in limited supply. Norwegian consumers eat an average of $5.4 \mathrm{~kg}$ of sheep meat per person per year, much of which is purchased as a frozen product. The Muslim (4.2\% of the population) preference for year-round halal meat, with an increased demand on the eve of the Muslim meat festival (Eid al-Adha), has the potential to boost demand, particularly in Oslo. This paper provides an overview of the Norwegian sheep farming system, the current market value chains, and the potential to meet the demand for halal meat in Norway (specifically during the Muslim meat festival-Eid al-Adha) to the advantage of both consumers and sheep farmers.
\end{abstract}

Keywords: halal; meat consumer; meat market; sheep farming; sustainable meat production

\section{Introduction}

While sheep farming is a part-time endeavour for most of the 14,000 Norwegian sheep flock owners, the industry is still vital for rural employment in Norway [1]. Over the past decade, sheep farming and sheep meat production have increased substantially. Recent figures from Statistics Norway [2] have shown that meat production has risen by $8.4 \%$ since 2012, while consumption increased by only $0.5 \%$ in the same period [3]. Norwegians consume a yearly average of $77.8 \mathrm{~kg}$ of meat per person of which $7 \%$ is from sheep [1]. The slaughtering of lambs and sheep is seasonal and so any meat in excess of demand for fresh consumption is frozen and stored for later use. Sheep farms are 
supported by government subsidies for production and the maintenance of open, cultural landscapes created through long-term livestock grazing. The sheep industry is investigating opportunities to improve market conditions to make sheep farming more profitable including increased grazing and decreased concentrate-feeding, thereby increasing national food self-sufficiency [4] and helping to maintain the pasture landscapes that are now threatened by woody plant encroachment $[5,6]$.

In Norway, approximately $4 \%$ of the population are Muslim. Meat dishes are of prime importance during Muslim festivals, especially Eid. The main festival is Eid al-Adha, the Muslim meat festival (MMF), where animals (preferably sheep) of a specified age ( $>12$ months old) are slaughtered, and meat is shared among the family (1/3), friends/neighbours (1/3), and the poor (1/3) [7]. This meat festival offers a significant marketing opportunity for the industry. However, Norwegian sheep farmers have yet to utilise the commercial opportunity of selling halal meat in general and meet the market demand generated by the Eid festival in particular.

Norwegian sheep farmers have adopted existing production strategies as the demand for sheep meat has varied little during the past few decades. However, a more recent influx of Muslim refugees and immigrants has created a new niche in the domestic market. An export market for halal products may also be a possibility. In this context, it is essential to understand the production practices of Norwegian sheep farmers in both inland and coastal areas, including the current patterns of slaughter, to see how they might meet production targets to service this opportunity. Improved availability of fresh meat throughout the year is also an important objective that would allow the establishment of a regular fresh halal meat supply chain. Adjustments to farming practices to allow the supply of fresh product year-round has the potential to improve the profitability of the industry while maintaining the grazing environment.

Norwegian farmers need to adjust the production system to account for the low price of sheep meat other than lamb in the domestic marketplace. The transportation of animals to and from summer highland grazing environments and the need to overwinter animals indoors, as well as the cost of storage of the frozen product for long periods, have added to the challenges in sustaining profitability. Norwegian rangelands can accommodate a higher number of grazing sheep-almost two times the current sheep population, according to research [8], so there is a potential for the industry to expand. The establishment of a tailor-made halal meat marketing chain may trigger changes that lead to higher profitability.

In this review article, Norwegian sheep farming is discussed as a case study to explore a new niche in meat marketing - the establishment of a sustainable halal meat value chain. This opens the possibility for the more efficient utilisation of meat from older ( $>1$ year) animals. We will briefly describe Norwegian sheep farming practices in the inland and coastal areas and the seasonal factors affecting out-of-season meat production in order to better facilitate sustainable halal meat supply in general and for the Muslim meat festival (MMF) specifically.

\section{Sheep Farming in Norway}

Of the Nordic countries, Norway has the largest sheep industry in terms of animal population and meat production (Table 1). Norwegian consumption of sheep meat per capita is the second highest of the Nordic countries, surpassed only by Iceland where the small human population and limited availability of grazing areas restrict production [1].

Table 1. Sheep population, mutton and lamb meat production, consumption, and import/export in the Nordic countries in 2011. Adapted from Åby, Kantanen, Aass, and Meuwissen [1].

\begin{tabular}{cccccc}
\hline Country & $\begin{array}{c}\text { Sheep } \\
\text { (Winter-fed Ewes) }\end{array}$ & $\begin{array}{c}\text { Flocks } \\
\text { (of Sheep) }\end{array}$ & $\begin{array}{c}\text { Mutton and Lamb } \\
\text { Meat Production } \\
\text { (Tonnes) }\end{array}$ & $\begin{array}{c}\text { Import/Export } \\
\text { (Tonnes) }\end{array}$ & $\begin{array}{c}\text { Per Capita } \\
\text { Consumption (kg) }\end{array}$ \\
\hline Denmark & 67,421 & 2380 & 2000 & $4630 / 1050$ & 1.2 \\
Finland & 129,100 & $657^{\mathrm{a}}$ & 950 & $2033^{\mathrm{c}} / 359^{\mathrm{c}}$ & 0.7 \\
Iceland & 474,759 & $2435^{\mathrm{b}}$ & 9587 & $23^{\mathrm{d}} / 2567$ & 18.8 \\
Norway & $1,045,495$ & 14,591 & 24,403 & $1545 / 25$ & 5.4 \\
\hline
\end{tabular}


Table 1. Cont.

\begin{tabular}{lccccc}
\hline Country & $\begin{array}{c}\text { Sheep } \\
\text { (Winter-fed Ewes) }\end{array}$ & $\begin{array}{c}\text { Flocks } \\
\text { (of Sheep) }\end{array}$ & $\begin{array}{c}\text { Mutton and Lamb } \\
\text { Meat Production } \\
\text { (Tonnes) }\end{array}$ & $\begin{array}{c}\text { e } \\
\text { Import/Export } \\
\text { (Tonnes) }\end{array}$ & $\begin{array}{c}\text { Per Capita } \\
\text { Consumption (kg) }\end{array}$ \\
\hline Sweden & 296,712 & 9387 & 5070 & $8277^{\mathrm{c}} / 350^{\mathrm{c}}$ & 1.5 \\
\hline $\begin{array}{l}\text { a year 2012, }{ }^{\mathrm{b}} \text { year } 2006,{ }^{\mathrm{c}} \text { year } 2010,{ }^{\mathrm{d}} \text { year } 2008,{ }^{\mathrm{e}} \\
\text { in Lamb and sheep meat are combined, as mutton production }\end{array}$ \\
in Norway is negligible.
\end{tabular}

Small, family-owned holdings dominate the Norwegian sheep farming system. There are currently more than 14,000 sheep farms in Norway, with 30\% of farms owning 20-49 winter-fed sheep per flock while $13 \%$ have more than 150 (Table 2) [9].

Table 2. The structure and winter-fed flock size of Norwegian sheep farms [9].

\begin{tabular}{ccccc}
\hline Flock Size & Farms & $\begin{array}{c}\text { Farms (\%) per } \\
\text { Flock Size }\end{array}$ & Ewes in Winter & $\begin{array}{c}\text { Sheep Number } \\
(\%) \text { per Flock Size }\end{array}$ \\
\hline $1-9$ & 761 & 5.2 & 4418 & 0.4 \\
$10-19$ & 1504 & 10.4 & 21,800 & 1.9 \\
$20-49$ & 4310 & 29.7 & 144,698 & 12.8 \\
$50-99$ & 4014 & 27.6 & 286,889 & 25.4 \\
$100-149$ & 2107 & 14.5 & 257,091 & 22.8 \\
$150-$ & 1827 & 12.6 & 414,465 & 36.7 \\
Total & 14,523 & 100 & $1,129,361$ & 100 \\
\hline
\end{tabular}

There are two main Norwegian sheep breeds-the Norwegian White Sheep (NWS), a crossbred combined meat-wool type, and the short-tailed, double-fleeced Spel sheep (Spel). The NWS constitutes $71.5 \%$ and Spel 19\% of the total Norwegian sheep population [10]. These breeds are supported by national breeding programmes with broad breeding goals, including improving lamb growth and ewe fertility [11]. Both breeds are first mated at seven months of age, and most ewes deliver their first litter at one year of age. Ewes are mated in autumn/winter with lambing in spring, maximising the utilisation of the short plant growth season [12] of the rangeland grazing areas to support lamb growth. The duration of the grass growing season varies across the country, ranging from 90 to 150 days.

The weather from coastal to inland areas changes considerably due to the Gulf Stream, which sweeps across the Atlantic Ocean from the Gulf of Mexico and up the Norwegian coast, providing a milder winter climate for Norway than most other countries at the same latitude. The average temperature falls below $0{ }^{\circ} \mathrm{C}$ (Figure 1), and most of the country is covered by snow in the winter season. However, in many coastal areas, the warmth of the Gulf Stream leads to intermittent snow cover. The mountain ranges bordering the inland areas block the effects of the Stream which lead to prolonged, relatively dry, and colder winters in the inland areas.

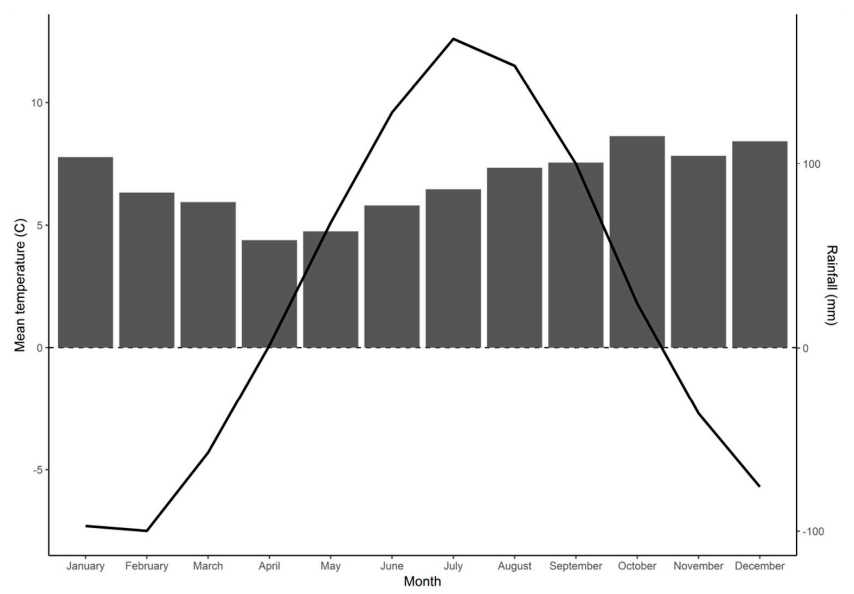

Figure 1. Average monthly temperature (line graph) and rain/snow-fall (bar graph) in Norway (1991-2015). Adapted from The World Bank Group [13]. 


\section{Rural Sheep Management in Norway}

Animal welfare concerns and winter season conditions are significant factors affecting sheep management and the livelihood of sheep farmers in Norway. There is little variation in the timing of the production cycle of sheep farms located in different rural areas across the country.

The sheep feeding system in Norway depends on ewes being barn-fed during the winter months. Lambing also usually occurs indoors followed by spring pasture grazing of sheep and suckling lambs on fenced land and summer range grazing mostly on unfenced highland pasture areas (Figure 2). Lambs that meet slaughterhouse specifications are separated from their dams at the end of the summer grazing period and transported to abattoirs, with slaughter peaking in September. As per the Norwegian Ministry of Agriculture and Food [14] directive, the time used to transport animals to a slaughterhouse must not exceed $8 \mathrm{~h}$. Lambs that have not reached an appropriate slaughter weight during summer grazing are transferred to fenced autumn pastures (if available) and may also be supplemented with concentrate feed for 3-4 weeks to reach a commercially acceptable bodyweight, usually deemed to be around $42-45 \mathrm{~kg}$ live weight.

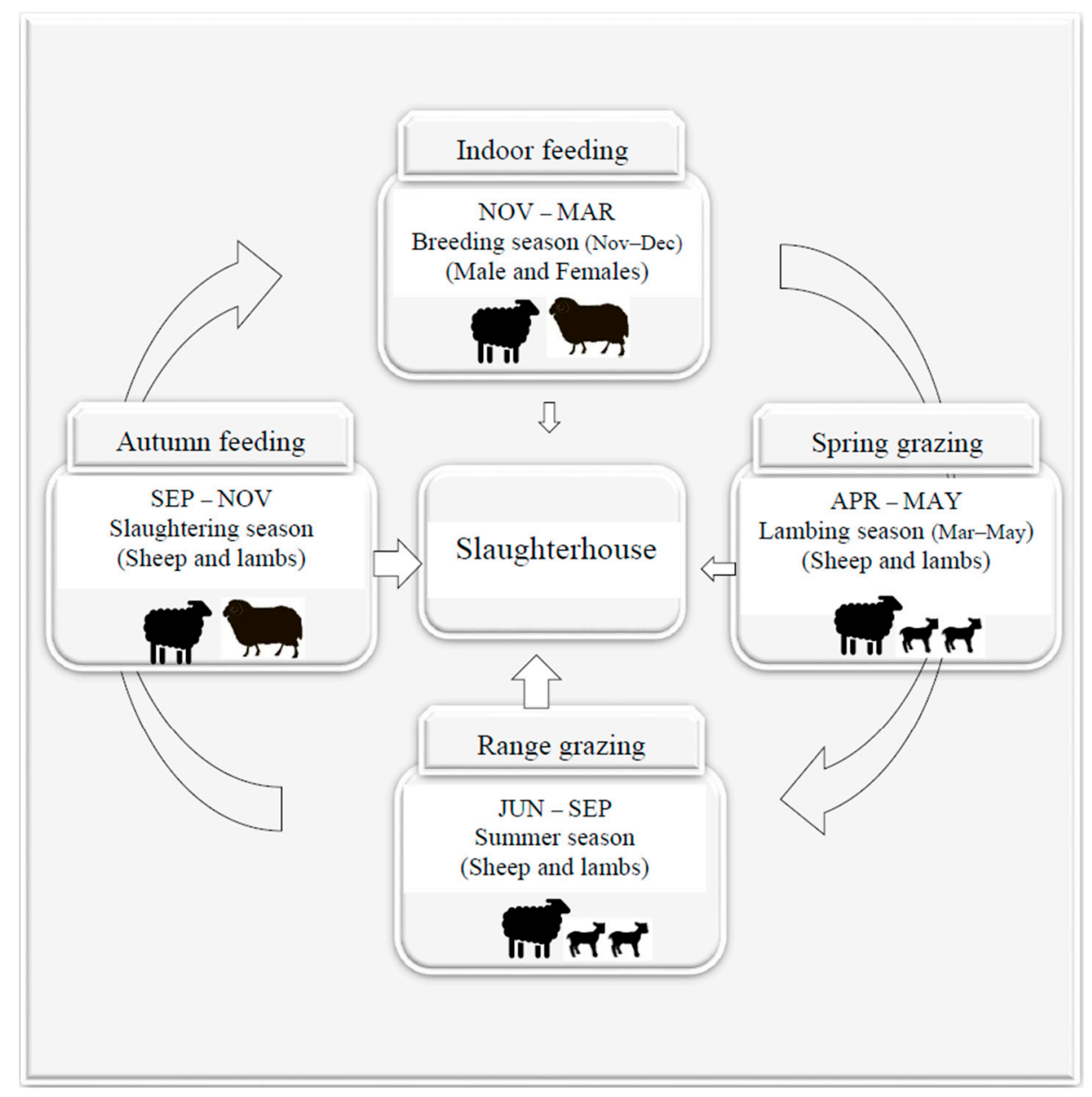

Figure 2. A typical Norwegian sheep production system (simplified layout). The length and placement of solid arrows pointing towards the slaughterhouse indicate the number of animals sent to the slaughterhouse and the time of year from the production cycle.

During the winter season, more than one million sheep are fed indoors. After lambing, the sheep population increases to 2.4 million [1]. Sheep numbers are not uniform throughout the country. Nine of the 19 Norwegian counties produce more than $80 \%$ of the lamb carcasses [15] (Figure 3). Rogaland County on the southwest coast is the main sheep meat producing region, supplying more than $27 \%$ of 
the total lamb carcasses in 2017. During spring and autumn, sheep in Rogaland are maintained on farm pasture at the highest stocking rates in the country (Statistics Norway) [2] (Figure 4). The numbers provided above are based on the registered location of the sheep farm. However, during the summer, rangeland-grazing sheep registered to one county may graze in neighbouring counties.

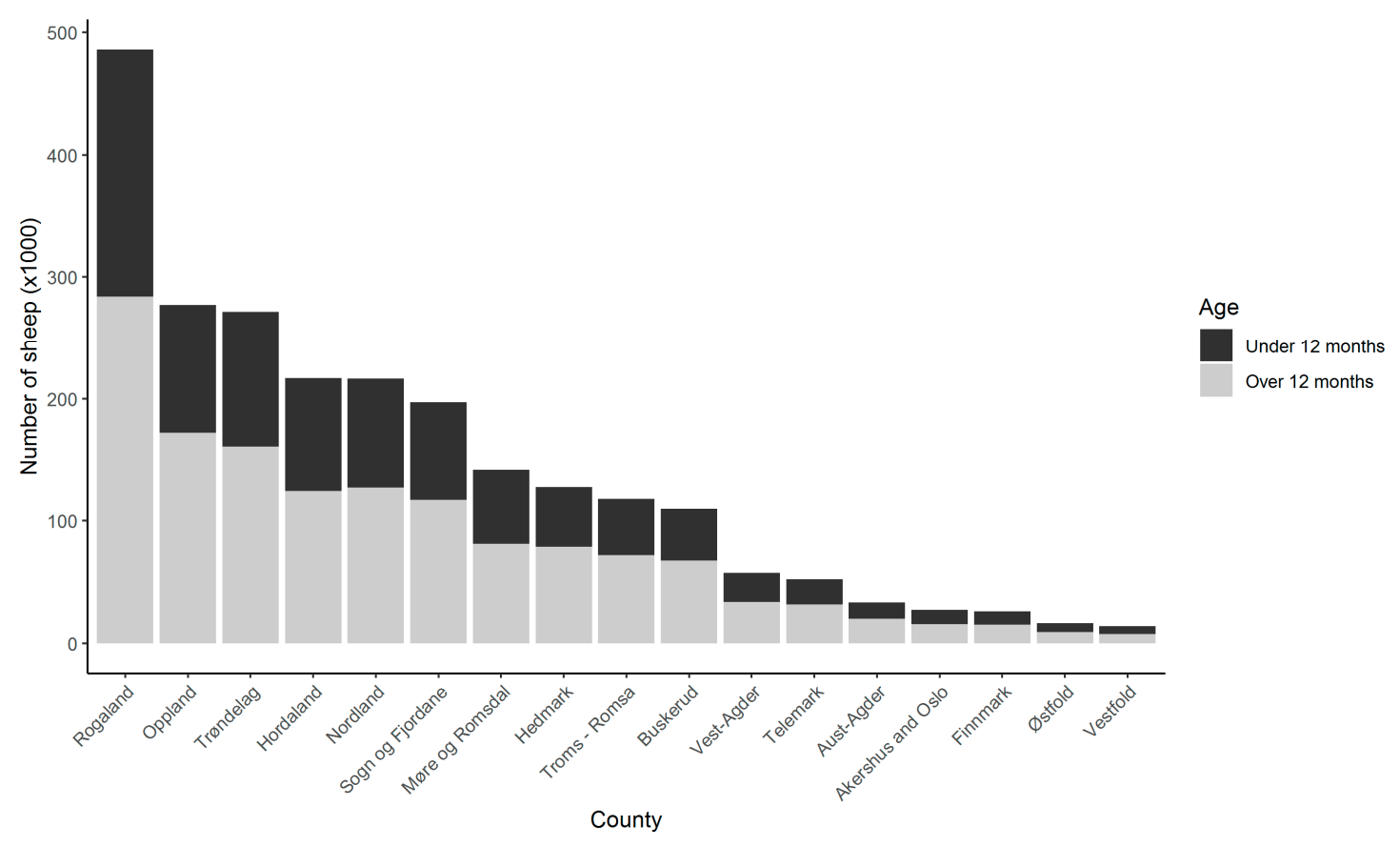

Figure 3. Norwegian sheep population in winter (under/over 12 months of age) in the 19 counties. Nord-Trøndelag and Sør-Trøndelag were merged in 2017 and are now referred to as Trøndelag. Data from Nord-Trøndelag and Sør-Trøndelag have been combined.

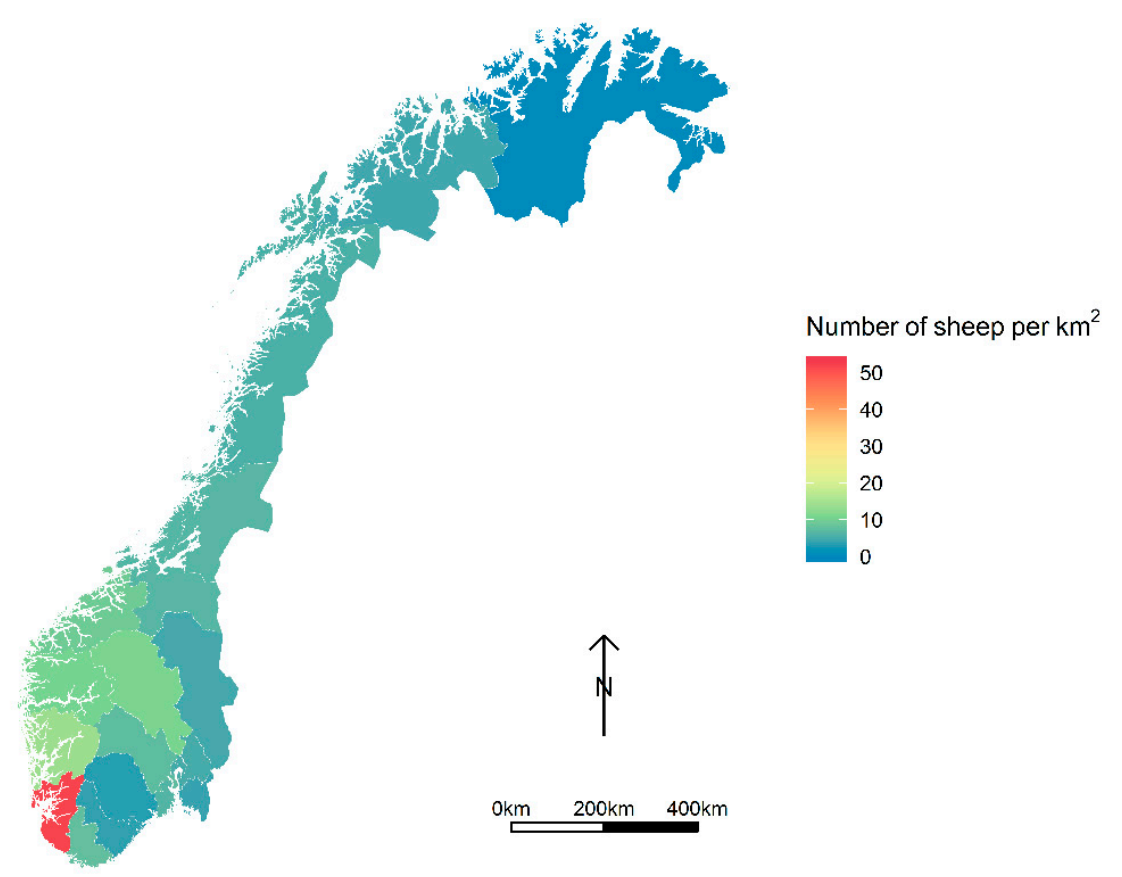

Figure 4. Sheep population density (per square kilometre) in Norwegian counties according to home farm location [10]. 


\subsection{Winter/Indoor Feeding}

During the indoor winter season, sheep are mostly fed grass silage or hey supplemented with concentrates and mineral feed. The number of sheep in winter flocks is minimised due to the higher costs associated with feeding, winter housing, and labour required for management [16]. Ewes are often fed according to their reproductive status later in the winter. Lambing takes place at the end of the winter season, mostly indoors with 3-4 weeks' variation in the time of lambing between regions (Figure 2).

\section{Inland vs. Coastal Areas}

Inland farmers facing colder winters with temperatures down to $-40{ }^{\circ} \mathrm{C}$ [17] are limited in their ability to expand their sheep flocks by grazing, while farmers along the western coast have more options available for sheep grazing. They may graze their sheep in high mountains during summer, lower mountains during the autumn, and sometimes along fjords or on islands during winter. Still, the use of this flexibility is not common today.

In some coastal areas, sheep farmers may graze their animals outdoors at all times due to the year-round availability of pasture (of varying quality) and milder temperatures [12]. This practice is mostly found on the west coast of Southern- and Mid-Norway.

\subsection{Spring Grazing}

After lambing in April-May, ewes and lambs are fed indoors before starting a short period of spring grazing on fenced land. The timing of lambing is synchronised with the typical spring flush of pasture growth in the area. Farmers who do not have adequate spring pastures may send their animals directly to open ranges at higher altitude. In the case of triplets or more lambs born per ewe, lambs are usually fostered ("fosterlam" in Norwegian) to another ewe or hand-reared ("kopplam" in Norwegian). Hand-reared lambs are typically kept in a fenced paddock with access to grass, milk or a commercial milk replacer, and concentrates. Lambs slaughtered by 3-4 months of age are defined as "dielam". Dielam is a rare product that attracts high market prices, since it is a fresh meat product supplied during the summer months that is tender compared to other sheep meat.

\subsection{Summer Grazing}

During summer, sheep graze on unfenced rangeland for an average 90-100 days. The rangeland pastures are a resource that is essentially free of cost, except for the labour cost of occasional monitoring of the flock for welfare purposes and for bringing the flock back to the farm in autumn. Upon their return from the open ranges, lambs are sorted based on size and conformation to slaughter criteria and are weaned from the dam. Lambs that meet the criteria, typically attaining a live weight of $\approx 43 \mathrm{~kg}$, are sent to the slaughterhouse, while smaller lambs are grown out on farm pasture or fed indoors [18]. Most rangeland pastures have an excess availability of dry matter during the summer months, though the quality decreases as the grazed plants mature. Lambs grazing high in the mountains have different meat quality characteristics compared to lambs grazed in lowland areas, with an increased content of beneficial polyunsaturated fatty acids [19]. Free-range summer grazing is an essential part of the Norwegian sheep farming system. Rangeland grazing provides an abundant resource capable of supporting a large number of sheep during the entire summer grazing season (Nationen, 2012). Reliance on rangeland grazing, however, leads to an over-supply of fresh lamb meat in autumn followed by nine months of a shortage of the fresh product.

\subsection{Autumn Feeding}

During autumn, unfinished lambs are fed indoors with silage and concentrate to attain high-quality carcasses with a variable meat flavour $[18,20]$. Lambs are kept on fenced pasture and concentrate may be offered indoors-animals have free access to pasture grazing and some 
indoor feeding. After 3-4 weeks of additional feeding, the majority of the lambs are slaughtered. Only breeding stock and lambs too small to be slaughtered are retained for indoor feeding.

The Fate of Ram Lambs

Pre-pubertal, non-castrated ram lambs are slaughtered during the main slaughter season. The castration of ram lambs has been uncommon and is now illegal in Norway based on welfare grounds. While painless methods using immune-castration technology are under development [21], the early-age slaughtering of ram lambs is currently the only management option for farmers. The maintenance of intact ram lambs above 4-5 months of age introduces the risk of unwanted pregnancies and meat may attain a ram taint $[20,22]$. The early slaughter of ram lambs reduces carcass yield and dressing percentage compared to yields from more mature female lambs of the same breed. On the other hand, decreasing the duration of grazing for female lambs and mature ewes minimises the utilisation of the upland grazing environment. In this context, the preferences of consumers should be considered and meat from ram lambs is highly favoured in the Punjabi kitchen, due to its traditional preference by Pakistani Muslims.

\section{Slaughtering Facilities in Norway}

There are 29 slaughterhouses in Norway, of which 14 are owned by the farmers' cooperative (Nortura AS), three by the private meat processor Fatland AS, and the rest by 12 small Norwegian enterprises [10]. During the peak slaughtering season from August to November (Figure 5), the surplus meat is usually stored in central meat chiller storage facilities and marketed by further dividing it among the meat processors within set quota limits for each processor/slaughterhouse. Quota are set according to a mutual understanding between the major meat processors. The price of sorted meat is currently regulated by the main meat processor, Nortura AS. However, the price of premium meat products and out-of-season products (if any) are decided by the meat processors as part of their internal business strategy. Farmers receive a number of government subsidies for sheep production and for the preservation of rural landscapes.

Of the 24,115 tonnes of mutton and lamb meat produced in 2008 [23], only 200 tonnes $(0.8 \%$ of total mutton and sheep meat produced) was halal [24]. Based on more recent data, Lever and Miele [25] showed that halal meat production had increased substantially, with Nortura alone selling 900 tonnes of halal product in 2012, showing a clear growth in demand for halal meat in Norway.

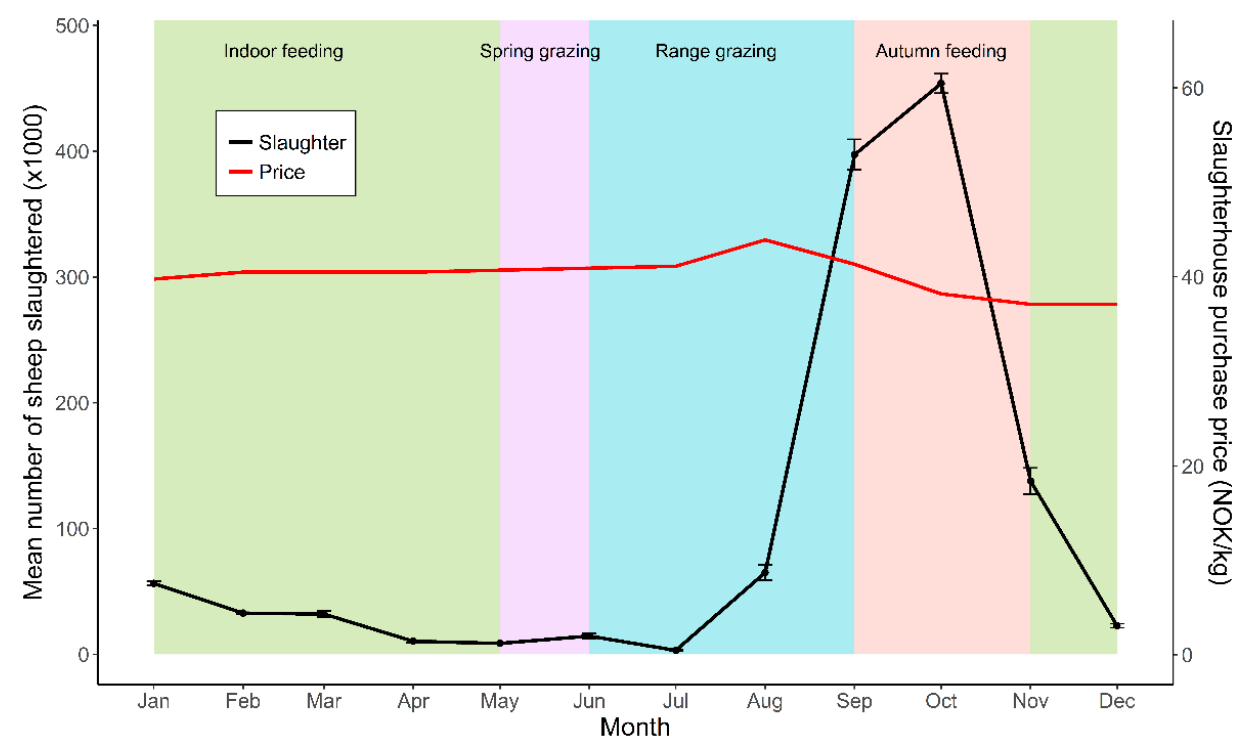

Figure 5. The number of sheep and lambs slaughtered per month and year (2014-2017) and average slaughterhouse purchase price (2017-2018). [15,26]. 


\section{Trends in Sheep Slaughter}

Based on age, Norwegian sheep carcasses are categorised into five classes—suckling lamb, lamb, young sheep, adult sheep, and ram. The mean carcass weight of lamb and sheep (pooled) increased from $22 \mathrm{~kg}$ in 2003 to $27 \mathrm{~kg}$ in 2009-10 (Figure 6). Since then, carcass weights have stabilised at 25-26 kg. If carcasses are categorised into four weight categories (Figure 7), the number of carcasses produced within the $0-16 \mathrm{~kg}$ class are at the same level in 2017 as in 1999 . However, the $24-40 \mathrm{~kg}$ class increased significantly after 2003.

The changes in average weight have resulted from a higher proportion of heavier sheep as farmers adjust their production system to maximise financial returns. Traditionally, breeding sheep have been kept for up to 8 years to maximise their lifetime productivity. However, today, more ewes are being slaughtered after 3-4 years, providing the marketplace with a higher quantity of mutton product (Figure 8).

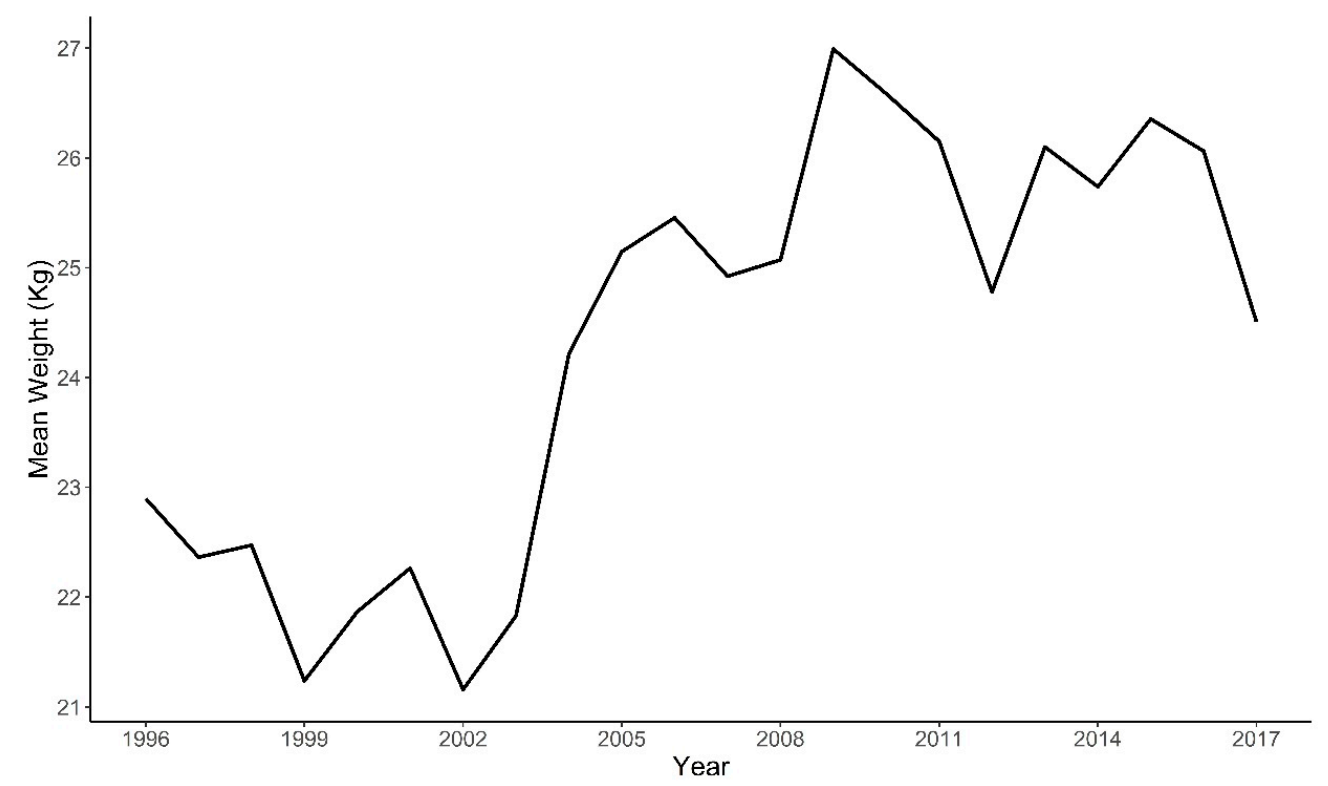

Figure 6. Lamb and sheep mean carcass weight (1995-2017).

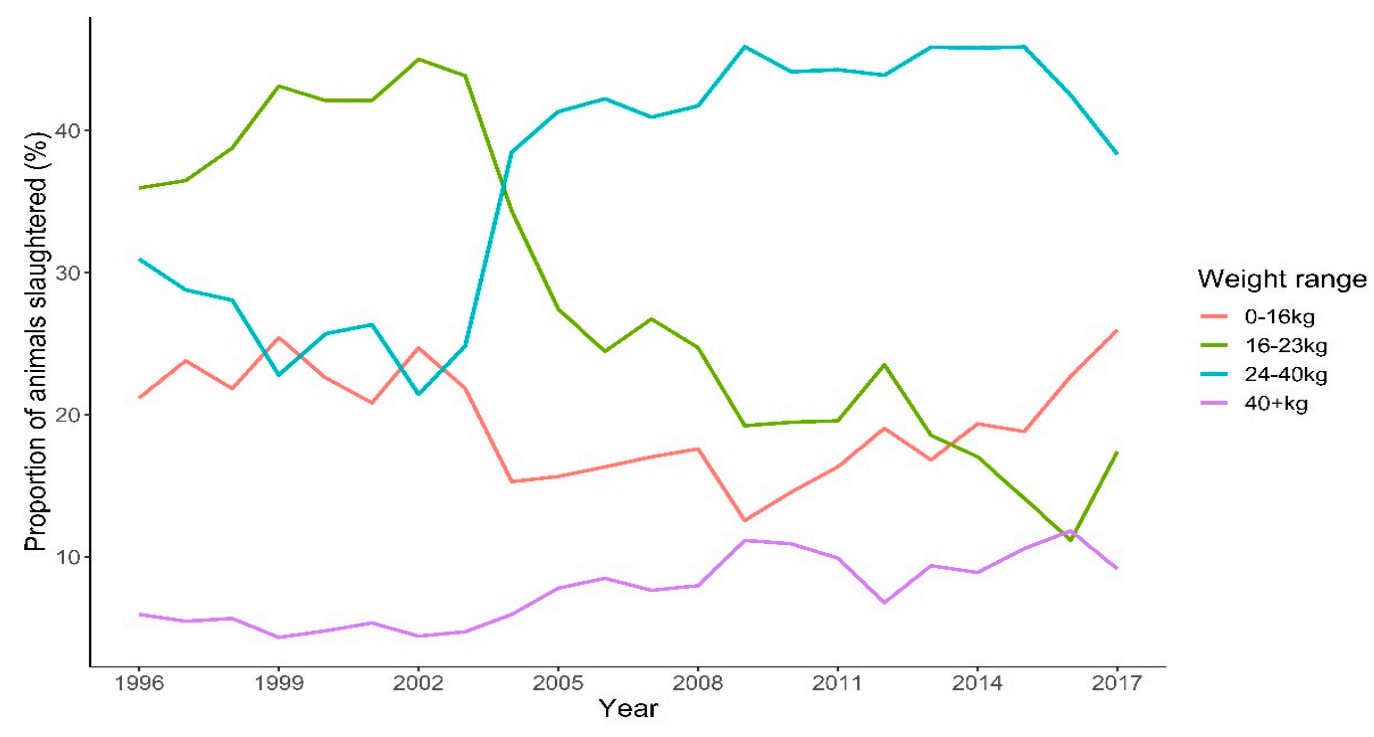

Figure 7. Sheep carcass weight group percentage (1995-2017) [15]. 
Carcass quality is assessed based on carcass conformation and fat status using the EUROP classification system. The EUROP conformation classification is not directly related to eating quality but is based on a visual inspection of the carcass, as described by Johansen et al. [27]. Carcass quality as classified by EUROP has improved since 2004 (Figure 9). Farmers generally obtain a good EUROP class for larger sheep carcasses; however, consumers often prefer smaller meat cuts based on their family size [28]. Relationships between the EUROP classification and consumer preferences are currently not well understood [29].

The percentage of each Norwegian sheep carcass category is shown in Figure 8. Since 2004, the quantity of suckling lambs and adult females has increased.

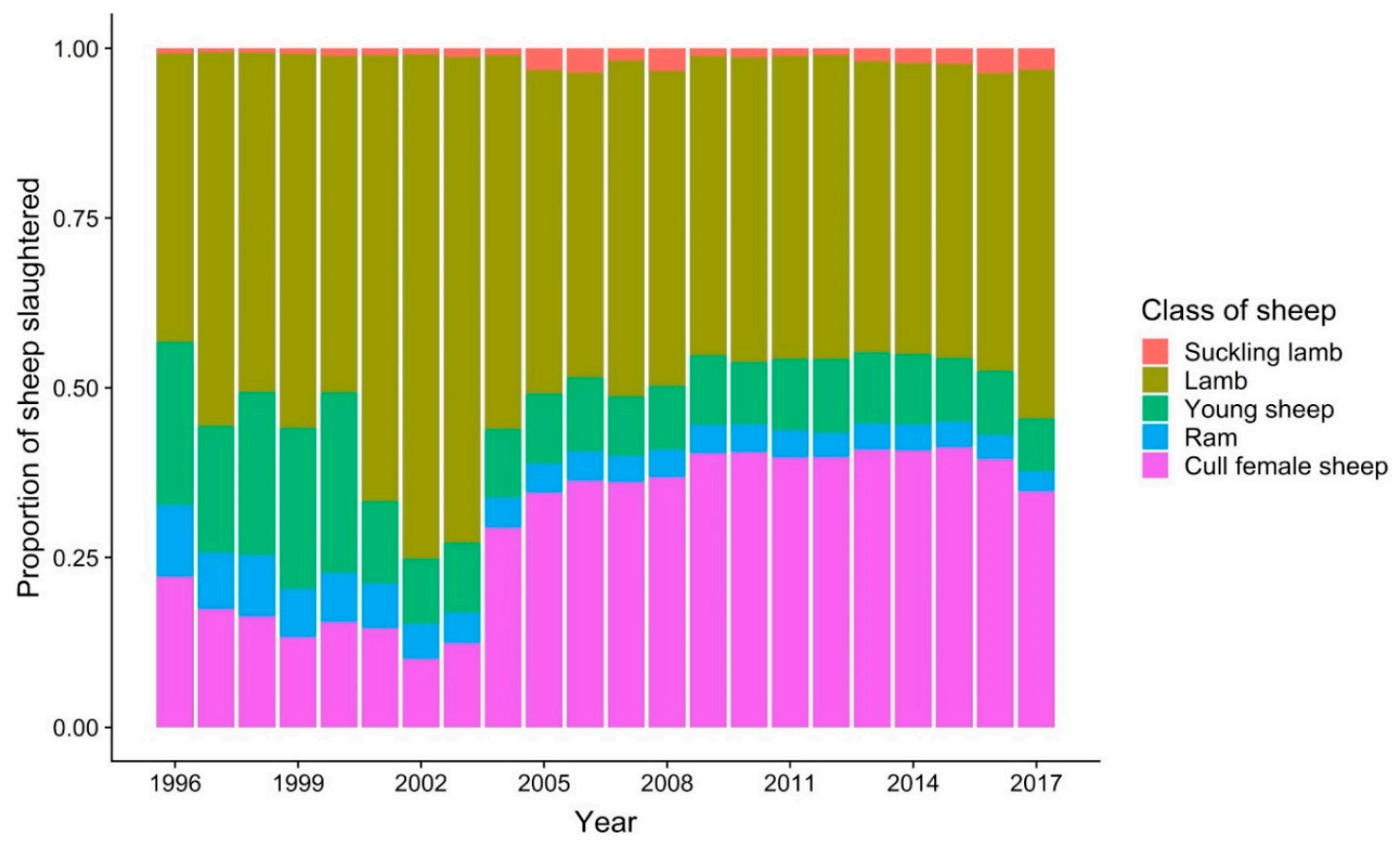

Figure 8. Proportion of types of sheep slaughtered (1995-2017).

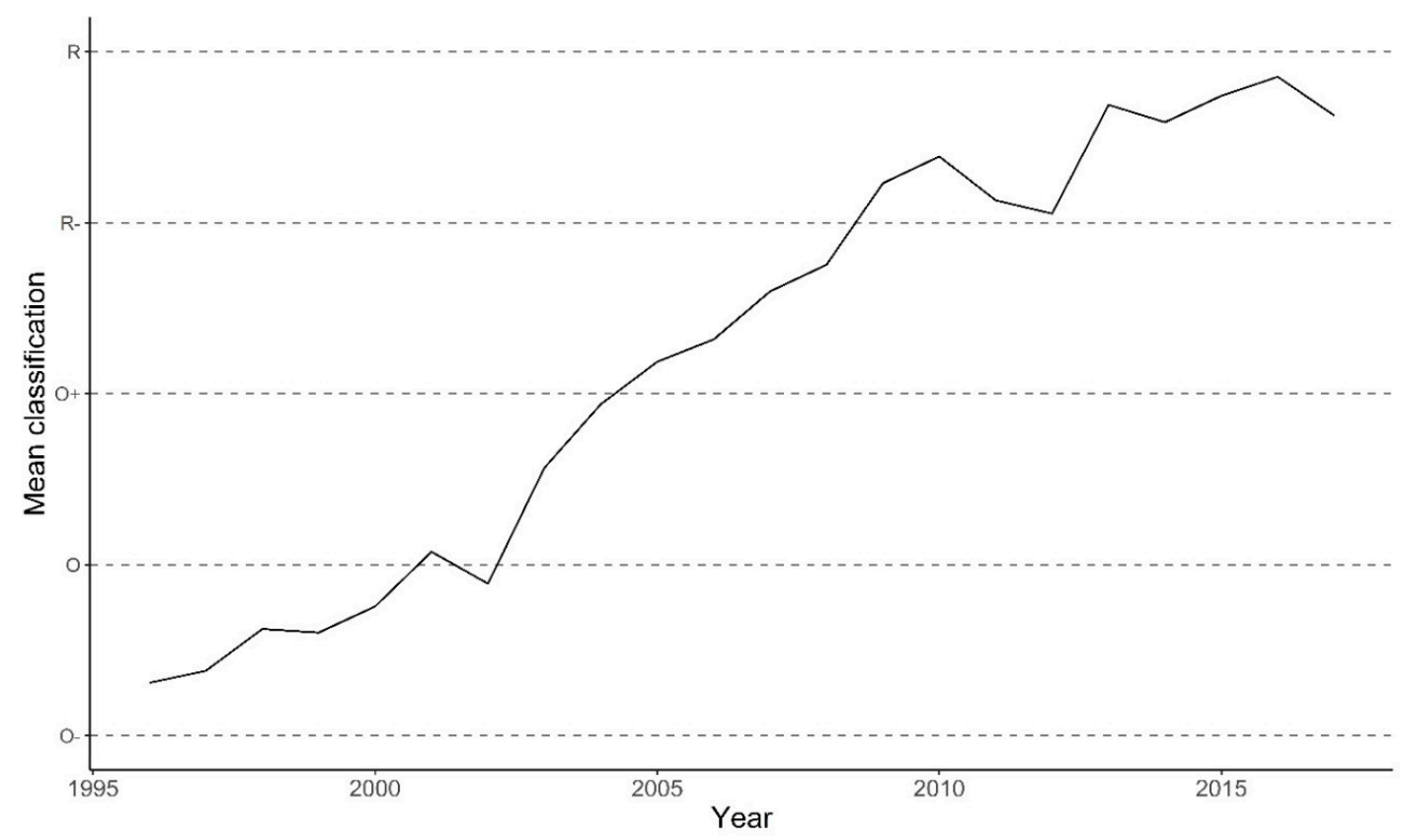

Figure 9. Mean EUROP confirmation classification of Norwegian lamb carcass (1995-2017). 


\section{Muslim Population and (Halal) Meat Consumption}

In Norway, Muslims represent the second largest religious community after Christians [30], with most originating from Pakistan [25]. Muslims are projected to constitute $6.1 \%$ of the Norwegian population by 2030 [31]. The demand for halal meat will thus increase, creating a market potential for the sheep industry if it can gain the more than 0.3 million Norwegian Muslim consumers' trust in local (halal) meat produced under the strict Norwegian food safety laws [32].

Islamic dietary laws, followed by most practising Muslims, place prime importance on the halal status of food products, especially for meat and meat products. The meaning of the word "halal" is "things or actions that are permissible under Islamic Sharia Law" [33]. The consumption of halal food meets Islamic religious requirements, while also meeting fundamental nutritional needs [7].

\section{Eid Al-Adha (Muslim Meat Festival—MMF)}

MMF is celebrated by Muslims throughout the world to commemorate the faith of Prophet Ibrahim (Abraham). This festival begins with the slaughtering of animals on the 10th of Dhu'l-Hijja, the last month in the Islamic calendar, and lasts for three days. On this occasion, all Muslims who can afford it purchase an animal, such as a sheep or a goat above one year of age, a cow ( $\geq 2$ years), or a camel, as a sacrificial animal. Keeping in view that the animal is slaughtered (halal) for religious reasons, physical traits, such as the colour and 'beauty' of the animal, are deemed important and determine the economic value of the animal in the halal meat market $[34,35]$.

In addition to the routine slaughtering practices required for the sheep meat to be halal, a Muslim person must bleed the animal in accordance with halal protocol. The process of slaughtering is critical, and halal slaughtering protocols must be followed [34]. The halal process can take place either in a registered slaughterhouse/abattoir (such as in Europe, the USA, or Australia) or at an informal place (government approved slaughterhouse/abattoir) specified by the local government on the eve of this meat festival (such as in most Muslim countries). In Norway, the halal slaughtering protocol (with some additional practices and approved food safety) is usually conducted using existing slaughterhouse practices. Therefore, on the eve of MMF, the slaughter of sheep ( $>1$ year old) occurs and the meat is delivered to the nearest grocery shops and sold alongside the regular array of meat products. After purchasing the halal carcass, the meat is equally divided among family, friends/neighbours, and the poor. In Muslim countries, people routinely purchase year-old sheep at least 1-2 months before the actual slaughter date. A livestock production system producing sheep $\geq 1$ year is needed to best fulfil the requirements for the MMF.

\section{Barriers for the Current (Halal) Meat Supply and MMF Celebration in Norway}

Currently, it is difficult for Norwegian Muslims to obtain halal slaughtered animals of sufficient age, especially during the MMF, for the following reasons:

- The Muslim meat festival does not usually coincide with the time of peak meat supply in Norway. Animals that could service this market are still grazing on rangeland pastures at the time of the festival (Figure 10) [36]. It is not profitable for farmers to bring down free-range grazing animals unless offered an exceptional price. However, the MMF offers a unique market for the slaughter of yearlings in Norway;

- A lack of infrastructure for the choice of animal, management, slaughter, and then delivery of meat often restricts consumer access to the halal product during the MMF.

As an alternative strategy in the provision of animal sacrifice at the MMF, the majority of Norwegian Muslim immigrants have their sacrificial animal selected and slaughtered in their country of origin, while residing in Norway. This is, however, considered a poor substitute for the traditional religious celebration of slaughtering the festival animal in situ. Norwegian Muslims sometimes send money equivalent to the price of a festival animal to charity organisations operating in their "home" 
country. The practice of slaughtering animals back in their home country may undermine the potential for halal meat demand and the increased production and sale of sheep and goat meat in Norway.

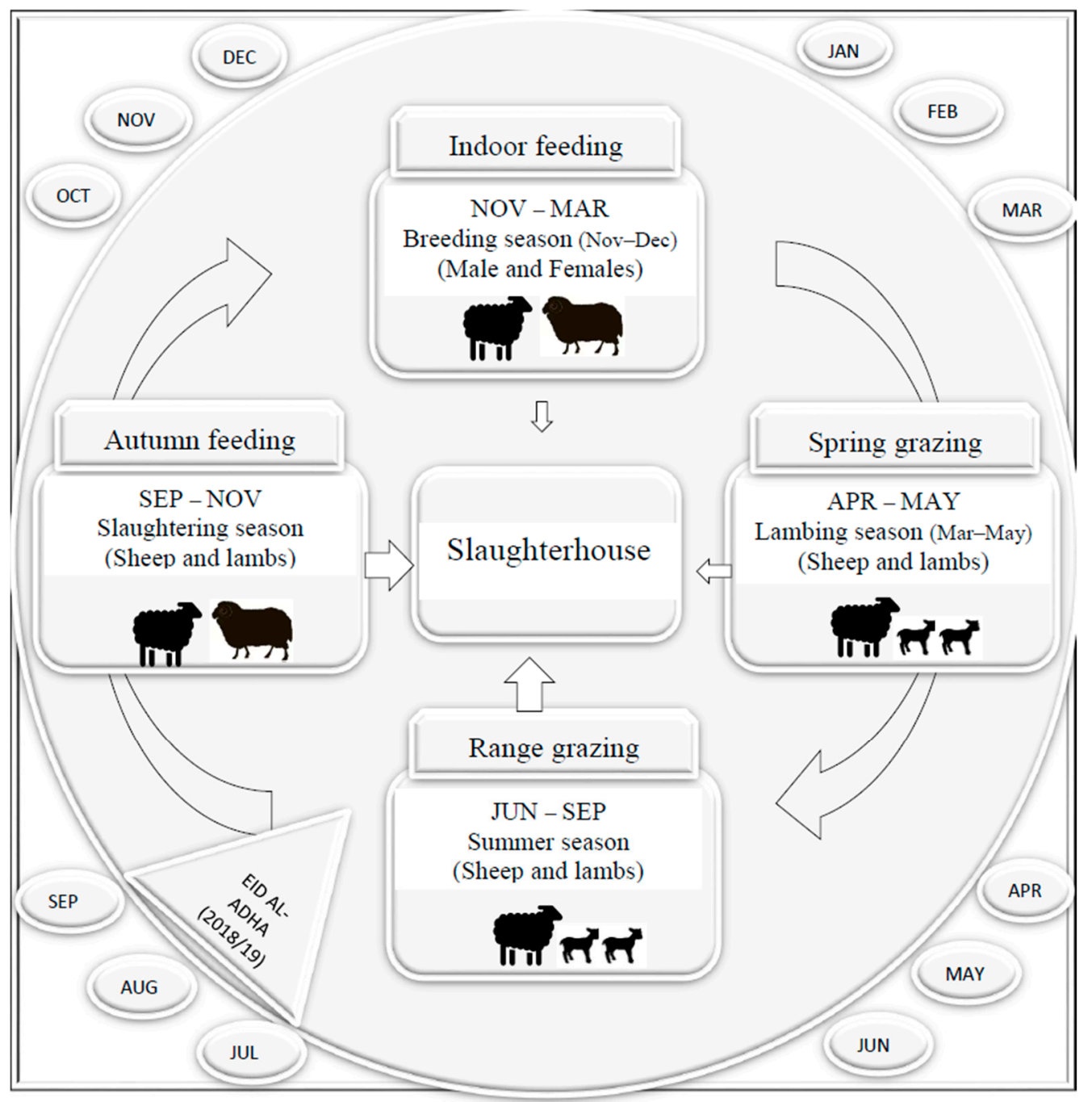

Figure 10. Potential for the integration of meat supply for the Muslim Eid festival into the Norwegian sheep farming system.

\section{Sheep Meat Production and Consumption Imbalance}

During the slaughter season (September-November) in 2017, more than 1.3 million sheep and lamb carcasses (27,445 tonnes of meat) were approved for human consumption [2]. Despite the higher demand for lamb meat at Christmas, these 1.3 million carcasses cannot be consumed as a chilled fresh product over this 3- to 4-month period. Moreover, it is challenging for slaughtering facilities to handle the concentrated slaughtering season [15]. A large quantity of meat/carcass is frozen for later use.

The need for farmers to reduce their flock size during the winter months, due to higher feeding and housing costs and the very low prices for older animals, restricts the potential to meet the requirements of the Norwegian halal market. Slaughtering during autumn seems the only option to restrict winter-stock numbers and get a good price per $\mathrm{kg}$ of lamb meat.

The frozen product does not provide the same sensory experience to consumers as fresh meat [37]. Sensory evaluation, tenderness, and juiciness are deemed superior in chilled meat compared to frozen-thawed meat produced in Norway [38]. Thus, the industry should develop new strategies for lamb production to maximise the availability of chilled products year-round. 
Existing Norwegian sheep production systems and slaughtering practices lead to the limited availability of fresh meat in the "off-season" and, in particular, do not meet the requirements of the MMF. Overall, the Norwegian market consumes meat worth USD 2.75 billion annually, including USD 1.5 billion worth of meat that is resold to retailers in the form of frozen meat. Despite occasional overproduction, Norway does not export sheep/lamb meat and actually imports lamb meat for, on average, $2-3 \%$ of its requirements [24].

\section{Discussion and Conclusions}

It is essential that the Norwegian meat industry reviews production and marketing chains to better meet the needs of an evolving consumer population. Norwegian sheep farmers receive government subsidies for the preservation of rural landscapes and food production based on natural resources. To maintain the popular support for agriculture and rural livelihoods, it is essential that the industry provides high-quality products. Consumer preference for meat from small ruminants will likely increase if the Norwegian industry can provide a consistent supply of high-quality fresh product without compromising the environment [39] and the low emission of greenhouse gases [40].

Norwegian sheep farmers operate within strict environmental boundaries. The availability of home-grown feeds for the winter is limited due to farm sizes and the short growing season. High-quality summer pastures are, on the other hand, abundant and freely available during the short summer months. Most of the summer grazing areas are found in mountainous areas, but forest grazing is also important during the summer and autumn seasons.

Like the Norwegian sheep meat industry, the British lamb industry has had to deal with similar challenges, but in their case, the frozen product was imported from New Zealand. In the United Kingdom, the import of sheep meat is declining continuously [41]. This is perhaps because British farmers changed from the traditional system of late lambing to a sustainable production system by adopting more than one lambing season per year. By doing this, they can utilise their home-grown lamb meat as a year-round fresh meat product and maintain better prices for farmers. This shows that it is possible to adjust production strategies to meet consumer needs that are beneficial for farmers-something that Norway might consider.

In general, a well-planned sheep farming system based on rangeland grazing will extend the use of natural feeding resources and, in addition to the strategic use of feed supplements, may improve economic and environmental sustainability [42-44]. A future diversification of Norwegian sheep production systems, producing either 5- to 6-month-old lambs (regular meat supply) or yearling animals (MMF supply) may lead to a more regular supply cycle, thereby reducing seasonal pressure on slaughter facilities while satisfying the MMF market. Further research including economic comparisons is required. Such work should focus on the natural and economic production constraints, and the nature of government subsidies provided for alternative production systems should also be considered.

One possible solution for the availability of off-season fresh meat is to focus more on a yearling production system using the Norwegian Spel breed. The yearlings can be better utilised for the MMF, and older lambs (born in May and slaughtered in February the next year) can provide fresh out-of-season meat. The price difference in lamb and sheep meat, a lower price offered for sheep meat, has resulted in more lamb meat production than sheep meat. More than $40 \%$ of the meat comes from sheep (Figure 8), which has resulted in a lower income due to the lower price offered per $\mathrm{kg}$ of sheep meat. The production of sheep meat can be reduced by slaughtering the animals at eight years thus increasing the lamb to sheep meat ratio.

In order to benefit from the growing halal meat market potential, Norwegian farmers need to rethink their production strategies to be able to meet the year-round demand for halal meat but with a particular emphasis on maintaining the supply for the peak demand around the time of key religious festivals. 
Increased production of the meat of animals that have reached one year of age, to cover the requirements for the MMF together with Easter and Christmas celebrations, should be a priority for the industry. Ewes are counted after the spring lambing season for calculating the government subsidy for production. Keeping ewes after lambing will assist in servicing the requirements of religious festivals, and farmers will be rewarded financially for keeping their sheep longer. It is also anticipated that more extensive early and late rangeland grazing of sheep in spring and autumn (where possible) will add to the national feedbase, with beneficial effects on the grazing environment. The maintenance of the rangeland environments should not be forgotten; it is vital for the rural landscape and the tourism industry, as well as the long-term livelihood of farmers.

A possible way to alleviate the imbalance during the concentrated slaughter season (August-October) is for coastal farmers, with access to a more extended plant-growing season, to adjust their breeding and lambing seasons to extend the slaughter season and therefore the period during which fresh lamb products are available to the consumer. Clear economic signals would need to be provided to facilitate changes in traditional farming practices.

In conclusion, modifications to the traditional sheep-rearing system including the production of yearlings for slaughter, has the potential to increase the sustainability of fresh off-season meat in the general Norwegian meat market and thus increase consumption. In addition, an improved fulfilment of Muslim meat demands will increase the Norwegian per capita meat consumption, thereby providing greater financial potential for sheep farmers. Further research focused on the economic analysis of yearling production systems and Muslim consumer meat-eating preferences is required. Cost-benefit economic analyses of traditional and yearling sheep-farming systems should help farmers to understand the current potential for a year-round increase in cash flow.

In order to make Norwegian sheep production economically sustainable [45], economic modelling of sheep-farming systems, with more focus on a sustainable year-round supply of sheep meat and supplying the halal market, will be required. To better understand the Norwegian Muslim meat consumers' perceptions and demands, a survey focusing on their meat purchase preferences, consumption, and trust in the meat industry will be conducted (by the present authors). This will play an important role in forming the best strategies for a sustainable Norwegian sheep industry.

Author Contributions: This paper is part of the PhD project of M.A.B. All the co-authors have substantially contributed in drafting and conceptualisation of the paper, revision of the paper and final approval of the version before submission. The diagrams preparation, M.A.B. and T.W.; critical review, D.L.H., P.C.W., L.O.E., T.Å., G.S. and L.J.A. The supervision L.O.E., G.S. and T.Å. The conceptualisation and review D.L.H., P.C.W., G.S., M.C., L.O.E. and T.Å. The project administration and funding acquisition, L.O.E.

Funding: This research was funded by Regionale Forskningsfond Vestlandet, Norway, Norwegian Research Council and Fatland Ølen AS, grant number 271952 (project: Fjorlam) and the Industrial PhD scholarship, grant number 277044. The APC was funded under the Fjorlam project.

Acknowledgments: The authors are thankful to Morten Røe from Animalia Norway for providing the data on animal slaughtering in Norway. We also acknowledge the Statistics Norway website for the available online data about sheep husbandry in Norway. The senior author is thankful to Fatland Ølen AS and the Norwegian Research Council for providing him with the PhD scholarship and Personal Overseas Research grant to visit Australia for three months. This article was partly written during Muhammad Azher Bhatti's Australian visit.

Conflicts of Interest: The authors declare that they have no conflict of interest.

\section{References}

1. Åby, B.; Kantanen, J.; Aass, L.; Meuwissen, T. Current status of livestock production in the Nordic countries and future challenges with a changing climate and human population growth. Acta Agric. Scand. Sect. A-Anim. Sci. 2014, 64, 73-97. [CrossRef]

2. Statistics Norway. Meat Production. 10 April 2018 Ed. Available online: https://www.ssb.no/en/slakt (accessed on 1 October 2018).

3. Norway Today. Norwegian Meat Consumption. Available online: http://norwaytoday.info/news/meatconsumption-still-increasing/ (accessed on 20 July 2018). 
4. Bay-Larsen, I.; Risvoll, C.; Vestrum, I.; Bjørkhaug, H. Local protein sources in animal feed-Perceptions among arctic sheep farmers. J. Rural Stud. 2018, 59, 98-110. [CrossRef]

5. Bernués, A.; Rodríguez-Ortega, T.; Alfnes, F.; Clemetsen, M.; Eik, L.O. Quantifying the multifunctionality of fjord and mountain agriculture by means of sociocultural and economic valuation of ecosystem services. Land Use Policy 2015, 48, 170-178. [CrossRef]

6. Stortingsmelding-11. Change and Development-A Future-Oriented Agricultural Production (Endring og Utvikling-En Fremtidsrettet Jordbruksproduksjon); Government of Norway: Oslo, Norway, 2016-2017; Section 8.2. Available online: https://www.regjeringen.no/no/dokumenter/meld.-st.-11-20162017/ id2523121/sec3 (accessed on 10 December 2018).

7. Riaz, M.N.; Chaudry, M.M. Halal Food Production; CRC Press: Boca Raton, FL, USA, 2003; eBook ISBN: 9780203490082. [CrossRef]

8. Nationen. Not Used-Large Potential on Rangeland Pastures. Available online: https:/ /www.nationen.no/ article/stort-uutnyttet-potensiale-i-utmarksbeite/ (accessed on 10 December 2018).

9. Statistics Norway. Livestock Husbandry. 10 August 2017 Ed. Available online: https:/ /www.ssb.no/en/ jordhus (accessed on 10 August 2017).

10. Animalia. Sauekontrollen. 2017. Available online: https://www.animalia.no/globalassets/sauekontrollen--dokumenter/arsmelding-2016-endelig.pdf (accessed on 9 November 2018).

11. Eikje, L.; Ådnøy, T.; Klemetsdal, G. The Norwegian sheep breeding scheme: Description, genetic and phenotypic change. Animal 2008, 2, 167-176. [CrossRef]

12. Karlsen, S.; Elvebakk, A.; Høgda, K.; Johansen, B.; Beck, P. GIMMS-NDVI based mapping of the growing season and bioclimatic zones in Fennoscandia and neighbouring parts of NW Russia. In Proceedings of the 31st International Symposium on Remote Sensing of Environment (IRSE), Saint Petersburg, Russia, 20-24 May 2005; pp. 20-24.

13. The World Bank Group. Climate Change Knowledge Portal. Available online: http://sdwebx. worldbank.org/climateportal/index.cfm?page=downscaled_data_download\&menu=historical (accessed on 27 July 2018).

14. Norwegian Ministry of Agriculture and Food. Regulations on the Nutritional Transport of Animals. Vol. LOV-2009-06-19-97-§6, LOV-2009-06-19-97-\$7, LOV-2009-06-19-97-\$11, LOV-2009-06-19-97-\$30, FOR-2010-06-11-814; Regulation (EC) No 1/2005 Annex I. Available online: https:/ /lovdata.no/dokument/ SF/ forskrift/2012-02-08-139 (accessed on 10 January 2019).

15. Animalia. Sheep: Number of Slaughter per Month and Year. 2017. Available online: http://statistikk. animalia.no/statistikk/vanligeGrafer/smaafe (accessed on 16 May 2018).

16. Skonhoft, A.; Austrheim, G.; Mysterud, A. A bioeconomic sheep-vegetation trade-off model: An analysis of the Nordic sheep farming system. Nat. Resour. Model. 2010, 23, 354-380. [CrossRef]

17. Norwegian Meteorological Institute. Weather statistics for Karasjok Kommune, Karasjok (Finnmark). Available online: https:/ / www.yr.no/place/Norway/Finnmark/Karasjok/Karasjok_kommune/statistics. html?spr=eng (accessed on 10 January 2019).

18. Lind, V.; Berg, J.; Eik, L.O.; Mølmann, J.; Haugland, E.; Jørgensen, M.; Hersleth, M. Meat quality of lamb: Pre-slaughter fattening on cultivated or mountain range pastures. Meat Sci. 2009, 83, 706-712. [CrossRef]

19. Ådnøy, T.; Haug, A.; Sørheim, O.; Thomassen, M.; Varszegi, Z.; Eik, L. Grazing on mountain pastures-does it affect meat quality in lambs? Livest. Prod. Sci. 2005, 94, 25-31. [CrossRef]

20. Lind, V.; Berg, J.; Eilertsen, S.M.; Hersleth, M.; Eik, L.O. Effect of gender on meat quality in lamb from extensive and intensive grazing systems when slaughtered at the end of the growing season. Meat Sci. 2011, 88, 305-310. [CrossRef] [PubMed]

21. Needham, T.; Lambrechts, H.; Hoffman, L. The influence of vaccination interval on growth, carcass traits and testicle parameters of immunocastrated ram lambs. Small Rumin. Res. 2016, 145, 53-57. [CrossRef]

22. Mushi, D.; Eik, L.; Sørheim, O.; Ådnøy, T.; Haugen, J. Effect of animal sex and time of slaughter on sensory quality of meat from Norwegian lamb. Acta Agric. Scand. Sect. A 2008, 58, 31-36. [CrossRef]

23. Statistics Norway. Agriculture Statistics 2008. 2009 Ed. Available online: https://www.ssb.no/en/jordskog-jakt-og-fiskeri/statistikker/slakt/aar/2003-04-01?fane=arkiv (accessed on 16 May 2018).

24. Lever, J.; Puig della Bellacasa, M.; Miele, M.; Higgin, M. From the Slaughterhouse to the Consumer: Transparency and Information in the Distribution of Halal and Kosher Meat; Dialrel Report; Cardiff University: Cardiff, UK, 2010; ISBN 1-902647-96-3. 
25. Lever, J.; Miele, M. The growth of halal meat markets in Europe: An exploration of the supply side theory of religion. J. Rural Stud. 2012, 28, 528-537. [CrossRef]

26. Fatland. Annual Price Fluctuations of Lamb's Meat Price to Producers at Fatland Ølen AS. Available online: http:/ / www.fatland.no/livdyr/smaafe/priser (accessed on 25 July 2018).

27. Johansen, J.; Aastveit, A.H.; Egelandsdal, B.; Kvaal, K.; Røe, M. Validation of the EUROP system for lamb classification in Norway; repeatability and accuracy of visual assessment and prediction of lamb carcass composition. Meat Sci. 2006, 74, 497-509. [CrossRef] [PubMed]

28. Hopkins, D.L.; Fowler, S.M. Australian Lamb Meat-The Response to Societal and Ethnic Influences. Korean J. Food Sci. Anim. Resour. 2018, 38, 653-663.

29. Polkinghorne, R.; Thompson, J.M. Meat Standards and Grading: A World View. Meat Sci. 2010, 86, $227-235$. [CrossRef] [PubMed]

30. Bolsgård, Ø. Religious Communities and Life Stance Communities. Available online: https://www.ssb.no/ en/kultur-og-fritid/statistikker/trosamf/aar (accessed on 10 February 2017).

31. Brunborg, H.; Texmon, I. Befolkningsframskrivning 2011-2100: Modell og Forutsetninger. 2011. Available online: https://brage.bibsys.no/xmlui/bitstream/handle/11250/178856/brunborg_texmon_2011.pdf? sequence $=1$ (accessed on 9 January 2019).

32. Ali, A.J. Organizational development in the Arab world. J. Manag. Dev. 1996, 15, 4-21. [CrossRef]

33. Al-Qaradawi, Y. The Lawful and the Prohibited in Islam; The Other Press: New York, NY, USA, 2013; ISBN 978-967-0526-00-3.

34. Al-Qaradawi, Y. The Lawful and the Prohibited in Islam (Al-Halal wal Haram fil Islam); American Trust Publications: Oak Brook, IL, USA, 1999.

35. Brooke, C. Sacred slaughter: The sacrificing of animals at the Hajj and Id al-Adha. J. Cult. Geogr. 1987, 7, 67-88. [CrossRef]

36. Asheim, L.; Mysterud, I. The Norwegian Sheep Farming Production System. Available online: http:/ / agris. fao.org/agris-search/search.do?recordID=QC1999000167 (accessed on 13 March 2019).

37. Coombs, C.E.; Holman, B.W.; Friend, M.A.; Hopkins, D.L. Long-term red meat preservation using chilled and frozen storage combinations: A review. Meat Sci. 2017, 125, 84-94. [CrossRef]

38. Lagerstedt, Å.; Enfält, L.; Johansson, L.; Lundström, K. Effect of freezing on sensory quality, shear force and water loss in beef M. longissimus dorsi. Meat Sci. 2008, 80, 457-461. [CrossRef]

39. Pickett-Baker, J.; Ozaki, R. Pro-environmental products: Marketing influence on consumer purchase decision. J. Consum. Mark. 2008, 25, 281-293. [CrossRef]

40. Garnett, T.; Godde, C.; Muller, A.; Röös, E.; Smith, P.; Boer, I.J.M.D.; Ermgassen, E.Z.; Herrero, M.; Middelaar, C.E.V.; Schader, C.; et al. Grazed and Confused?: Ruminating on Cattle, Grazing Systems, Methane, Nitrous Oxide, the Soil Carbon Sequestration Question—and What It All Means for Greenhouse Gas Emissions; FCRN: Oxford, UK, 2017.

41. Oborne, R. Lowest UK Imports of Sheep Meat for at Least 20 Years; Agriculture \& Horticulture Development Board: Warwickshire, UK, 2018; Available online: http:/ / beefandlamb.ahdb.org.uk/market-intelligencenews / lowest-uk-imports-sheep-meat-least-20-years / (accessed on 3 January 2019).

42. Croston, D.; Pollott, G. Planned Sheep Production; Collins: London, UK, 1985.

43. Keady, T.; Hanrahan, J.P.; Flanagan, S. Effects of extended grazing during mid, late or throughout pregnancy, and winter shearing of housed ewes, on ewe and lamb performance. Ir. J. Agric. Food Res. 2007, 46, 169-180.

44. Chaudhry, A.S. Forage based animal production systems and sustainability, an invited keynote. Revista Brasileira de Zootecnia 2008, 37, 78-84. [CrossRef]

45. Malcolm, B. Farm management analysis: A core discipline, simple sums, sophisticated thinking. AFBM J. 2004, 1, 40.

(C) 2019 by the authors. Licensee MDPI, Basel, Switzerland. This article is an open access article distributed under the terms and conditions of the Creative Commons Attribution (CC BY) license (http:/ / creativecommons.org/licenses/by/4.0/). 